\section{Compromise disappoints}

\section{London}

POLAND's academics, while delighted with the re-legalization of Solidarity, are disappointed with the compromise which is the outcome of their six weeks of negotiation with the government at the socalled round table, which brought together government and opposition interests.

The universities had been hoping that the 1985 Higher Education Act would be annulled, returning the regulation of Poland's universities to the framework of the earlier legislation inspired by the Solidarity period of $1980-81$. But, instead, there is to be a new law from the autumn of 1990 restoring to universities a measure of control over financial, curricular and staffing decisions. Meanwhile, interim regulations will, from next September, bringing an end to some of the most resented restrictions.

Thus the Minister of National Education will no longer be able to veto the granting of doctorates on ideological grounds, and representatives of students and non-teaching staff will once again

\section{SPACE ADMINISTRATION \\ West Germany founds space agency}

\section{Munich}

THE West German cabinet agreed on 26 April to coordinate its space programme through a new private agency, to be known as DARA (Deutsche Agentur für Raumfahrtangelegenheiten $\mathrm{GmbH}$ ). The agency will be overseen by a committee of cabinet members led by the Research and Technology Minister.

By organizing DARA as a private agency, the government hopes to gain flexibility in the planning and carrying out of space missions. The agency will be supported by contracts from various ministries for tasks such as remote sensing, telecommunications and research. The DARA budget will start at DM30 million and increase to DM55 million in the near future. The agency is expected to have 300 employees.

Establishing the agency took years despite an obvious need. A political struggle between the recently reorganized German Aerospace Research Establishment (DLR) and the Research and Technology Ministry accounted for some of the delay (see Nature 328, 6; 1987).

Two vital decisions remain for DARA. A director has to be nominated by a board of directors, which itself still has to be formed. And a site has to be found. Chancellor Helmut Kohl has decreed that the agency should be located in Bonn's immediate surroundings.

Steven Dickman Asia. participate in senate and departmental committees. Lecturers dismissed on ideological grounds have been promised reinstatement, although it is not clear how their seniority can be restored without the creation of further posts. And, starting immediately, permission to travel abroad on academic business is in the gift of university rectors; the consent of the Ministry of National Education will no longer be required.

Although Solidarity has been legalized, there is a delay in dealing with the proSolidarity Independent Students' Association (NZS). The authorities are still pressing for a formula to limit the militancy of NZS, whose disturbances at Kraków during March at one stage imperilled the whole concept of the round table.

NZS held its second national conference at Wroclaw last month. A major split developed between 'radicals', who refuse to accept government constraints, and moderates who urge that, while the organization remains illegal, it has no means of making students' grievances known except by demonstrations.

Among other things, NZS is concerned about the condition of the Warsaw University library, where underspending and the neglect of conservation for several decades have put at risk many of the collections of rare and historical manuscripts. NZS organized a demonstration on the issue in mid-April, but says that if it were given legal status, it could be more constructive, perhaps organizing fundraising drives.

Meanwhile, there will be several distinguished academics among those standing for the forthcoming elections to the bicameral parliament. The candidates for the Senate include Dr Wladyslaw Findeisen, the former rector of Warsaw University who was sacked in 1985 for having refused to discipline students attending the funeral of the murdered priest Father Jerzy Popieluszko.

The candidates for the lower house (Sejm) cover almost all scientific and academic disciplines. There are four mathematicians, one physicist, one zootechnician, two geologists, an astronomer - as well as two students.

Vera Rich

\title{
International telecommunications
}

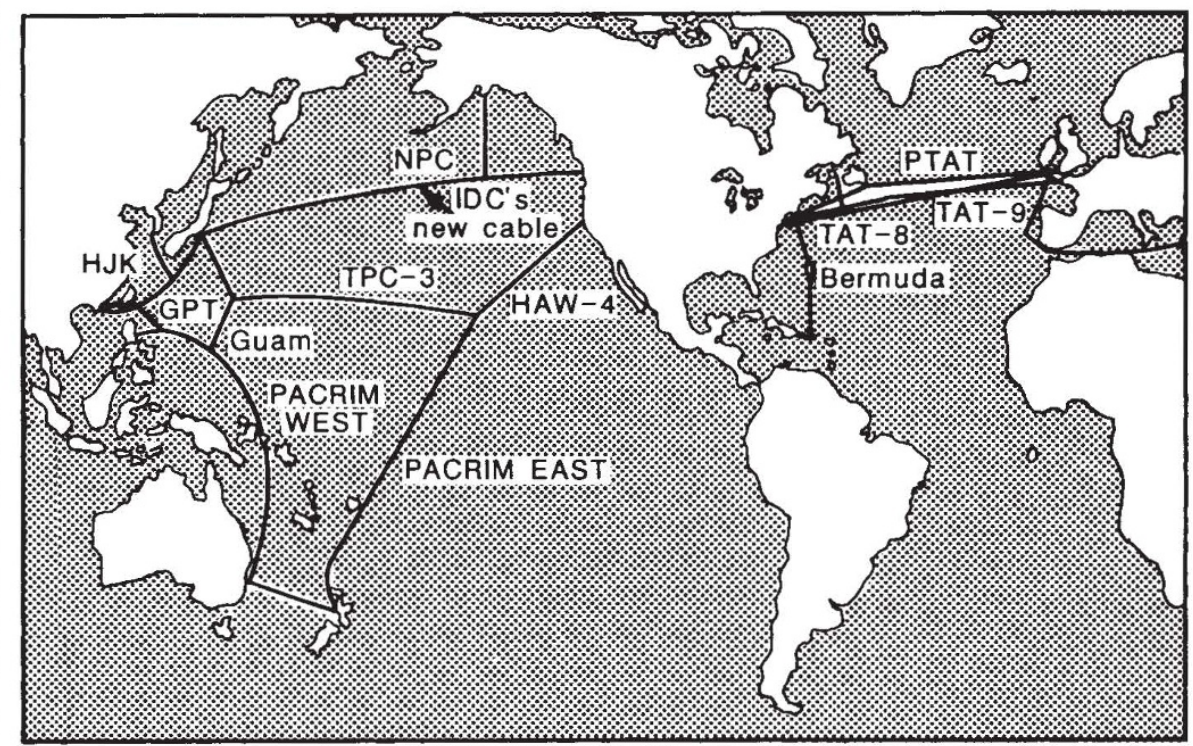

A NEW Japanese telecommunications company established by Cable and Wireless of the United Kingdom began international services last week. The company, International Digital Communications (IDC), was the centre of a trade dispute with Britain and the United States two years ago when Japan at first refused to grant the foreign-backed company an operating licence (see Nature 326, 319; 1987). The costs of international telecommunications in Japan are expected to drop significantly as a result of the new competition.

IDC is initially offering leased data-transmission services at rates 20 per cent below those of Japan's international telecommunications giant Kokusai Denshin Denwa (KDD). Another new telecommunications company, International Telecom Japan, which is backed by a consortium of Japanese companies, also began a similar service last month. Ordinary telephone services will begin in October, according to a spokesman for IDC.

All three companies are at present using Intelsat satellites and a new trans-Pacific opticalfibre cable (TPC-3), which was completed last month. But IDC and Cable and Wireless will also lay their own trans-Pacific cable (NPC) which will come on line in December next year. IDC's new cable, which will link Japan to Alaska and Oregon via a submarine branching point off the US coast, will form part of a global optical-fibre network connecting Europe, the United States and

Davld Swinbanks 